\title{
Oligodynamic Action of Silver, Copper and Brass on Enteric Bacteria Isolated from Water of Kathmandu Valley
}

\author{
Rajani Shrestha ${ }^{1}$, Dev Raj Joshi ${ }^{2}$, Jyotsna Gopali ${ }^{1}$ and Sujan Piya ${ }^{3}$ \\ ${ }^{I}$ National College, Kathmandu, \\ ${ }^{2}$ Central Department of Microbiology, Tribhuvan University, Kathmandu, \\ ${ }^{3}$ College of Medicine, Chosun University 375, South Korea \\ e-mail:joshi_devraj@hotmail.com
}

\begin{abstract}
Traditionally certain metal pots are used to store drinking water in order to ensure safety. A study was conducted with the aim of evaluating the effect of oligodynamic metals such as copper, silver and brass against enteric gram negative drinking water isolates such as Salmonella paratyphi, Shigella spp., E. coli (MDR), E. coli, Vibrio cholerae and Klebsiella spp. in Kathmandu. The study was conducted at the microbiology laboratory of National College, Kathmandu during September 2007 to January 2008. The test was carried out by preparing broth of the respective microorganisms followed with contaminating autoclaved distilled water with $1 \%$ (by volume) of the prepared broth culture and incubating the contaminated water in the respective metal pots up to $48 \mathrm{~h}$ (holding time). Reduction in the microbial load was assessed by pour plating the water content in the metal pots on Nutrient agar medium in every $0,4^{\text {th }}, 8^{\text {th }}, 12^{\text {th }}, 24^{\text {th }}$ and $48^{\text {th }} \mathrm{h}$ of incubation (holding time). Among three test pots, copper pot showed the maximum bactericidal action compared to silver and brass pots towards most of the enteric gram negative bacterial isolates of water. Complete inhibition of tested organism was recorded within 4 to 48 hours of holding time. This study suggested the promotion of use of water pots made of oligodynamic metals such as silver and copper, and alloy such as brass to control the gram negative enteric pathogens in drinking water.
\end{abstract}

Key words: oligodynamic action, heavy metals, enteric bacteria

\section{Introduction}

Oligodynamic action is the ability of small amounts of heavy metals to exert a lethal effect on bacterial cells. Definite metals and metal compounds confer in minute quantity of water solutions the ability to change and finally kill cells of microrganisms in a characteristic way. Oligodynamic metals, such as silver and copper, have long been utilized as disinfectants for non-spore-forming bacteria and viruses (Thurman \& Gerba 1988). Silver can serve as a disinfectant at concentrations about 1,000 times lower than the toxic level to mammalian life (Warrington 1996). Many metallic elements have been observed to inhibit the growth of bacteria and to inactivate enzymes. Practical application of such activity of metals has been made in the purification of water and in the preservation of tomato juice, cider and hides. This antimicrobial effect is shown by metals such as mercury, silver, copper, lead, zinc, gold, aluminum and other metals, and the concentration of the metal needed for this antimicrobial effect is extremely small (Jain 1990).

The exact mechanism of this action is still unknown but some data suggest that the metal ions denature protein of the target cells by binding to reactive groups resulting in their precipitation and inactivation. The high affinity of cellular proteins for the metallic ions results in the death of the cells due to cumulative effects of the ion within the cells (Benson 2002). Similarly, silver inactivates enzymes by binding 
with sulfhydryl groups to form silver sulfides or sulfhydryl-binding propensity of silver ion disrupts cell membranes, disables proteins and inhibits enzyme activities (Thurman \& Gerba 1988; Semikina \& Skulacher 1990). The study also suggest that positively charged copper ion distorts the cell wall by bonding to negatively charged groups and allowing the silver ion into the cell (Hambidge 2001). Silver ions bind to DNA, RNA, enzymes and cellular proteins causing cell damage and death (Hambidge 2001). Both gram positive and negative bacteria are affected by the oligodyanmic action of heavy metals. However, there are several bacterial strains that contain genetic determinants of resistance to heavy metal (Bopp et al. 1983). These determinants for resistance are often found in plasmids and trasposons (Summers 1985).

In the present study, we demonstrated oligodynamic action of some heavy metals and alloy against gram negative enteric pathogens isolated from drinking water in relation to holding time in water. Thus the study explores further use of oligodymic metal pots for decontamination of drinking water.

\section{Materials and Methods}

The study was conducted at National College, Kathmandu during September 2007 to January 2008.

\section{Test organisms}

Gram negative enteric pathogens such as Escherichia coli, multi drug resistant E. coli, Salmonella paratyphi, Shigella spp, Vibrio cholerae and Klebsiella spp. were isolated from different drinking water sources in Kathmandu valley by culture based microbiological techniques (Benson 2002).

\section{Preparation of inoculums}

Pure colonies of test organisms were transferred to $5 \mathrm{ml}$ nutrient broth and incubated at $37{ }^{\circ} \mathrm{C}$ for $4 \mathrm{~h}$ until the turbidity of the prepared inoculums was matched with McFarland tube number 0.5 (Prepared by adding $0.6 \mathrm{ml}$ of $1 \% \mathrm{w} / \mathrm{v}$ barium chloride solution to $99.4 \mathrm{ml}$ of $1 \% \mathrm{v} / \mathrm{v}$ solution of sulphuric acid).

\section{Oligodynamic metal pots}

Household metal pots of silver, copper and brass were selected for the study. Three metal pots of silver, copper and brass were selected and sterilized by rinsing with alcohol for 10-15 minutes and then dried in oven.

\section{Oligodynamic activity of metals}

The metal pots were then filled with appropriate volume of autoclaved distilled water. The water in all three metal pots was then contaminated with broth culture prepared from the water isolate $(1 \%$ broth culture of the total volume of water content in the pot). The contaminated water samples from the pots was then pour plated at the interval of $0,4^{\text {th }}, 8^{\text {th }}, 12^{\text {th }}, 18^{\text {th }}, 24^{\text {th }}$ and $48^{\text {th }}$ h of incubation (holding time). The total numbers of the bacterial colonies were counted and the reduction of the bacterial density in water sample with increasing holding time interval in the metal pots was recorded.

\section{Results}

The oligodynamic action of all test heavy metals was exhibited within $48 \mathrm{~h}$ holding time. All tested gram negative enteric pathogens isolated from drinking water sources were inhibited in water within maximum holding time. However, effectiveness of metals and susceptibility shown by individual bacteria were different in each case.

Copper pot showed the total reduction in microbial load of Salmonella paratyphi after $4 \mathrm{~h}$ of holding time while $100 \%$ load reduction was obtained after 8 and $24 \mathrm{~h}$ holding time with silver and brass pots respectively (Fig. 1).

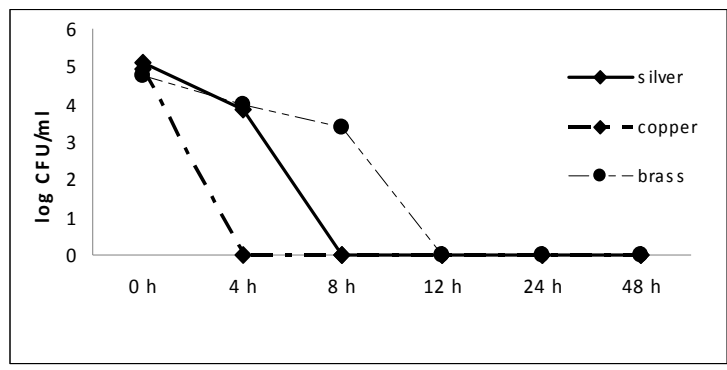

Fig. 1. Oligodynamic action shown by Salmonella paratyphi

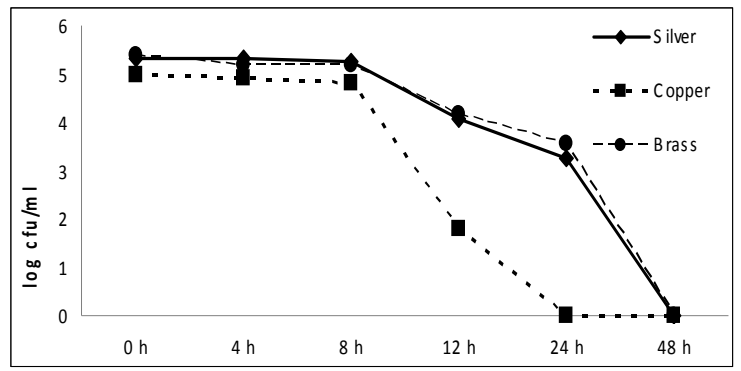

Fig. 2. Oligodynamic action shown by Shigella spp. 
Comparatively, the density of Shigella spp. was lately reduced. The total reduction in the bacterial load was achieved after $24^{\text {th }}, 48^{\text {th }}$ and $24^{\text {th }} \mathrm{h}$ of holding time with silver, copper and brass pots respectively (Fig. 2).

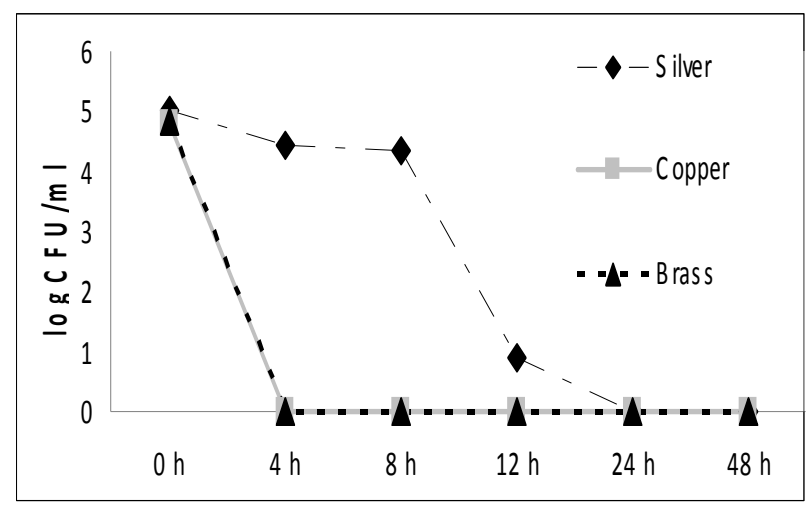

Fig. 3. Oligodynamic action shown by E. coli

Escherichia coli population was found more susceptible to oligodyanamic metals. The load of $E$. coli was reduced completely with $4 \mathrm{~h}$ of holding time with copper and brass pots but total reduction in the microbial load was achieved only after $24 \mathrm{~h}$ holding time with silver pot (Fig. 3).



Fig. 4. Oligodynamic action shown by multidrug resistant E. coli

Multidrug resistant $E$. coli isolated from water was inhibited lately in terms of holding time in metal pots. The bacterial load was reduced totally after $24 \mathrm{~h}$ of holding time with silver and brass pots while this was achieved only after $48 \mathrm{~h}$ of holding time with copper pot (Fig. 4).

\section{Discussion}

Traditionally it has been believed that drinking water stored in certain metal pots is comparatively less contaminated with microorganisms indicating the potential role of the pot material in decreasing bacterial density. In this study, the oligodynamic metals (silver, copper and brass) were evaluated for their effectiveness to control bacterial contamination in water for $48 \mathrm{~h}$ against the gram negative enteric water isolates: Salmonella Paratyphi, Shigella spp., E. coli, multi-drug resistant E. coli, Vibrio cholerae and Klebsiella oxytoca.

Shahi et al. (1996) tested five types of traditional pots for the bactericidal action against $E$. coli (ATCC 25922). Copper, silver and brass pots were found to be very effective against the $E$. coli culture while steel and aluminium pots were found less effective toward the $E$. coli isolates. In our study, copper was found more effective against the E. coli compared to silver and brass. This might be due to the impure nature of the silver that was used in making the pot used in this study thereby arose the question in the purity of silver that was used in making the pot found in the market currently or might be due to the fact that the isolate was really less effective towards the silver. So, to enhance the oligodynamic effect, copper and other oligodynamic metal, can be combined with silver resulting in a synergistic disinfection effect on bacterial cells so that the positively charged copper ion distorts the cell wall of microorganisms by binding to negatively charged groups and allowing the Silver ion into the cell (Hambidge 2001).

In this study, interestingly the multidrug resistant E. coli was found to be inhibited by metals only in extended time period. Naturally occurring copperresistant microorganisms are common in the environment (Jain 1990). There are various factors on which the metal tolerance or resistance in the microbes depend. The most common resistance on metal and antibiotics is the result of bio-essentiality or abuse of the metal and/or antibiotics (Hideomi et al. 1977). Tolerance and resistance of bacteria has also been shown to increase proportionally along industrial contamination gradients (Osborn et al. 1997 \& Roane et al. 1996). The genetic factor is another important factor that produces the metal resistance. Many research and studies done previously by different persons and agencies have reported the co-existence of the metal 
and antibiotics resistance. Genes that code for antibiotic resistance traits and genes that code for metal resistance are often carried on the same plasmids or mobile genetic elements (Yurieva et al. 1997). Similar bacterial resistance to multiple heavy metals was reported from Providence River and the Narragansett Bay (Traxler \& Wood 1980). This transfer of virulence, conjugative, and antibiotic and metal resistance phenotypes may result in the increased dissemination of antibiotic and metal resistance determinants to bacteria in the environment.

The next probable reason for the metal resistance of the water isolate may be due to the pre-exposure of metal through various industrial contaminations because the residual effects of most of these heavy metals on aquatic biota are long lasting, as they can be non-available due to complex formation with organic matter. Thus they are not easily eliminated from these ecosystems (Forstner \& Wittmann 1979). Similarly bacteria are a potentially important source of metal accumulation in filter-feeding mollusk like limpets as ingestion of bacteria contributed for the metal accumulation (Qiu et al. 2001) and this result suggests that water of Kathmandu valley is contaminated by the heavy metals.

This study also explores the possibilities of using these metal products or their salts as disinfectants. The particular characteristics of electrochemical silver, such as the mode of action, effectiveness at low concentrations, and stability, indicate that silver could be used effectively in preservatives (Simonetti et al. 1992). Furthermore, the inhibitory and bactericidal concentrations of electrically generated silver ions are 10 to 100 times lower than for silver sulfadiazine. Effects of silver ions on normal mammalian cells are minimal (Berger et al. 1976).

Conclusively, all tested metals, copper, silver and brass showed the oligodynamic action towards the enteric bacteria isolated from drinking water of Kathmandu valley but among these three metals, copper proved to be the best oligodynamic metal against most of the water isolates. Therefore, copper can be used in filters and is the right choice for storing water which and less expansive as compared to silver.

\section{Acknowledgement}

The authors are thankful to National College, Kathmandu for providing laboratory facilities and also partial financial support.

\section{References}

Benson, H.J. 2002. Microbiological applications: Laboratory manual in general microbiology. Eighth Edition. McGraw Hill: New York.

Berger, T.J., J.A. Spadaro, S.E. Chapin and R.O. Becker. 1976. Electrically generated silver ions: Quantitative effects on bacterial and mammalian cells. Antimicrobial Agents and Chemotherapy 9(2):357-8.

Bopp, L.H., A.M. Chaktrabarty and H.L. Ehrlich. 1983. Chromate resistance plasmid in Pseudomonas flourescens. Journal of Bacteriology 173: 31493158.

Forstner, U. and G.T.W. Wittmann. 1979. Metal pollution in the aquatic environment. Springer Verlag, New York.

Hambidge, A. 2001. Reviewing efficacy of alternative water treatment techniques. Health Estate 55: 23-25.

Hideomi, N., T. Ishikawa, S. Yasunaga, I. Kondo and S. Mitsuhasi. 1977. Frequency of heavy metal resistance in bacteria from inpatients in Japan. Nature 266: 165-16.

Jain, R.K. 1990. Copper-resistant microorganisms and their role in the environment. World Journal of Microbiology and Biotechnology 6(4):356-365: 356-365.

Osborn, A.M., K.D. Bruce, P. Strike and D.A. Ritchie. 1997. Distribution, diversity and evolution of the bacterial mercury resistance (mer) operon. FEMS Microbiology Review 19: 239-262.

Qiu, J.W., P.Y. Qian and W.X. Wang. 2001. Contribution of dietary bacteria to metal accumulation in the Slipper Limpet. Aquatic Microbial Ecology 25: 151-161.

Roane, T.M. and S.T. Kellogg. 1996. Characterization of bacterial communities in heavy metal contaminated soils. Canadian Journal of Microbiology 42: 593-603.

Semikina, A. L. and V. P. Skulacher. 1990. Submicromolar $\mathrm{Ag}+$ increases passive $\mathrm{Na}^{+}$permeability and inhibits the respiration supported formation of $\mathrm{Na}^{+}$ gradient in Bacillus FTU vesicles. FEBS 269 (1):69-72. 
Shahi, R., M.P. Baral and T.M. Pradhananga. 1996. Oligodynamic action of traditional Nepalese water pots against E. coli (ATCC 25922). Paper presented at the $2^{\text {nd }}$ international seminar on water and environment, Kathmandu, Nepal.

Simonetti, N., G. Simonetti, F. Bougnol and M. Scalzo. 1992. Electrochemical Ag+ for preservative use. Applied and Environmental Microbiology $\mathbf{5 8}$ (12):3834-3836.

Summers, A.O. 1985. bacterial resistance to toxic elements. Trends Biotechnology 3: 122-125.

Thurman, R.B. and C.P. Gerba. 1988. The molecular mechanisms of copper and silver ion disinfection of bacteria Q2 and viruses. Crit. Rev. Environ. Cont. 18: $295-315$.
Traxler R.W., E.M. Wood. 1980. Multiple metal tolerance of bacterial isolates. In: Developments in industrial microbiology. Vol. 22. (Eds. L.A. Underkofler \& M.L. Wulf), Flagstaff, AZ (USA). pp 521-528.

Warrington, P.D. 1996. Application of criteria for aquatic life. Water Quality Branch, British Columbia Ministry of Environment, Lands and Parks, Environmental Protection Department. Retrived from http://wlapwww.gov.bc.ca/wat/wq/ BCguidelines/ silver/bcsilver-04.htm.

Yurieva, O., G. Kholodii, L. Minakhin, Z. Gorlenko, E. Kalyaeva, S. Mindlin, and V. Nikiforov. 1997. Intercontinental spread of promiscuous mercury resistance trasposons in environmental bacteria. Molecular Microbiology 24: 321-329. 
Nepal Journal of Science and Technology 10 (2009) 